\title{
IR spectra of porous silicon based nanocomposites
}

\author{
Kristina A. Ganichkina*, Diana R. Suyundukova, and Natalya V. Latukhina \\ Samara National Research University, 34 Moskovskoe shosse, Samara 443086, Russian Federation \\ *e-mail: ganichkina.k@mail.ru
}

\begin{abstract}
The article is devoted to the problem of using porous silicon (por-Si) as a biomaterial. IR spectroscopy was used to study the composition of por-Si samples and nanocomposites: por-Si with hydroxyapatite, promising as a biomaterial for osteoplasty and por-Si with glucose (for biosensor). The studies were carried out on the FSM 2201 Fourier spectrometer using the diffuse reflection prefix and Perkin Elmer Spectrum 100 using the total internal reflection violation prefix. A comparative analysis of the results shows a noticeable difference between the IR spectra of nanocomposites and the IR spectrum of the original por-Si and allows to identify the substance in the pores. (C) 2019 Journal of Biomedical Photonics \& Engineering.
\end{abstract}

Keywords: glucose; hydroxyapatite; nanocomposite; biosensor; IR spectroscopy.

Paper \#3313 received 30 Jan 2019; revised manuscript received 3 Apr 2019; accepted for publication 1 May 2019; published online 27 May 2019. doi: 10.18287/JBPE19.05.020303.

\section{Introduction}

The future of medicine is to increase the accuracy of diagnosis and dosage of drugs, working out of medicinal agent with a new principle of effect, which should lead to an increase in the duration of a full human life. Nanomaterials and nanotechnologies play an indispensable role in solving these problems. Biosensors based on nanomaterials open up wide possibilities of obtaining information much faster, easier and more accurate than it happens with the help of traditional analysis. The role of nanotechnology is also important in the creation of bone and other implants, where nanoporous and nanocomposite materials show better survival in the body.

Por-Si with a developed pore system and, as a consequence, a large area of the inner surface, is promising for various medical applications, as well as other porous nanomaterials. An additional advantage is its biocompatibility, while the por-Si can be both bioresistant and bio-resorbable, and its dissolution products are non-toxic $[1,2]$. Promising areas of por-Si application in medicine may include the creation of a microchip of the artificial retina [3], the destruction of cancer cells using por-Si nanoparticles $[4,5]$, the cultivation of biological tissues on the por-Si surface $[6,7]$, the creation of nanostructured containers for drug delivery $[8,9]$, ultra-sensitive biosensors $[10,11]$, and much more. The presence of a large number of pores allows the use of por-Si to create a variety of nanocomposites, which further expands the scope of its possible applications.

The purpose of our work is to determine the possibility of using the por-Si for the blood glucose biosensor, and the possibility of creating biomaterials for osteoplasty based on nanocomposites of silica with hydroxyapatite (HAP) - mineral phase of bone. For this purpose, the IR spectra of material samples based on por-Si nanocomposites with glucose and HAP were studied. Analysis of IR spectra allows determining the phase composition of the material, the presence of the necessary substances and the absence of undesirable ones.

\section{Porous silicon as a biomaterial for medicine}

\subsection{Bone implants based on hydroxyapatite and silicon}

Developed chemically active surface and high adsorption capacity in relation to biological and organic molecules determines the possibility of using por-Si as a substrate for tissue growth. The possibility of growth on the surface of por-Si of a wide variety of biological tissues, from skin and bone to brain tissue, has been experimentally shown [6,7]. The advantages of using por-Si in polymer-based materials for osteoplasty are 
also shown $[12,13]$. Por-Si based biodegradable material, which applied to the fracture area, will ensure rapid recovery of the damaged bone without the use of any pins or tires and over time will be completely replaced by the patient's own bone tissue [13].

At the initial stage, silicon plays a significant role in the formation of bone, accelerates the process of calcification, which contributes to faster and stronger bone formation. Silicon ions in combination with hydroxyapatite fill the "skeleton" of the bone at the molecular level and make the skeleton tissue more dense [13].

HAP saturated por-Si can serve as a basis for the creation of transport particles for the delivery of hydroxyapatite to the affected areas of the bone in case of any injuries or diseases, for example, osteoporosis $[14,15]$. There is important that during the saturation of the HAP pores absence of chemical interaction of substances with the formation of undesirable insoluble compounds such as silicates or silicides, is need, because such interaction will worsen the dissolution of transport particles and reduce the proportion of useful "building material". In this regard, the study of IR spectra of nanocomposite por-Si + HAP is very important.

\subsection{Prospects of creating a biosensor based on porous silicon}

Por-Si is a promising platform for the creation of biosensors. The diversity of the pore structure leads to a variety of optical, electrical and mechanical characteristics of the material. An important feature of porous silicon is its high adsorption capacity to biological and organic molecules. Adsorption affects electronic properties, the change of which leads to changes in the type and nature of surface active centers. This property of silicon is used in medicine to create materials for biosensors $[16,17]$.

The first glucose-determining biosensor, ExacTech (MediSense), used an electrode containing glucose oxidase as an enzyme [18]. However, it is possible to create a biosensor based on a por-Si without the use of enzymes, because the modification of the surface of the por-Si leads to different values of the sensitivity to glucose and the correct choice of the parameters of the layers it is possible to obtain the maximum value of sensitivity.

The optical properties of porous silicon are the promise for creating biosensors. Optical methods of blood glucose determination are the most attractive because they are safe for humans [18-20]. One of the promising optical methods is the method of analysis of IR spectra of human physiological fluids - blood, plasma, saliva, tears [20]. Therefore, in this work, the study of IR spectra of por-Si composites with aqueous glucose solutions was carried out.

\section{Methods of creation and investigation of nanocomposites from your por-Si}

\subsection{Creation of nanocomposite samples}

The method of horizontal electrochemical etching (Fig. 1) was used to obtain por-Si samples. Silicon wafers with three different types of surfaces: faceted, textured and polished were used. Initially, the silicon plates are cleaned of organic contaminants, they are boiled for 5 minutes in a solution of hydrogen peroxide $\left(\mathrm{H}_{2} \mathrm{O}_{2}\right)$, ammonia hydrate $\left(\mathrm{NH}_{4} \mathrm{OH}\right)$ and water $\left(\mathrm{H}_{2} \mathrm{O}\right)$, mixed in a ratio of 1:1:4 and dried at room temperature.

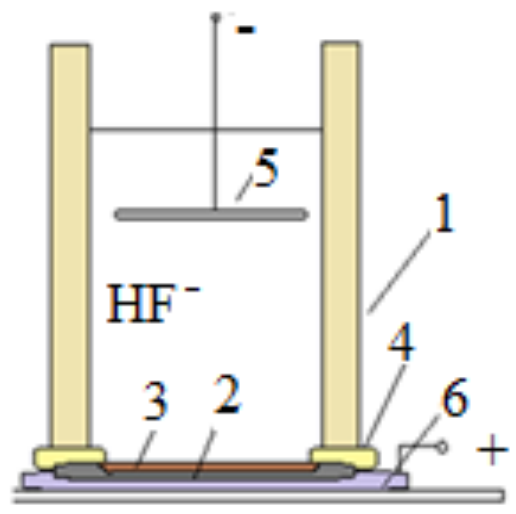

Fig. 1 The scheme of the electrolytic cell for the formation of layers of porous silicon (1 - fluoroplastic bath, 2 - silicon wafer, 3 - layer of porous silicon, 4 - seals, 5 - platinum electrode, 6 - metal electrode).

After that, the plate is placed in an electrolytic cell. A silicon plate is placed on the metal electrode, a fluoroplastic bath is installed on it, which is then filled with electrolyte, the platinum electrode is immersed in the electrolyte. In the process, electrolytes based on aqueous-alcoholic solutions of hydrofluoric acid with the addition of ammonium fluoride were used. Etching lasted 20, 25 and 30 minutes at a voltage $U=30 \mathrm{~V}$ and a current $\mathrm{I}=40 \mathrm{~mA}$. Etching under these conditions is quite equal, building up a system of vertical parallel pores ten micrometers deep. The pore depth depends on the etching time and anode current density.

To create a glucose nanocomposite the solutions of glucose powders $\left(\mathrm{C}_{6} \mathrm{H}_{12} \mathrm{O}_{6}\right)$ in water with different concentration were used. Por-Si nanocomposite with HAP was created by hap deposition on a substrate from a suspension in ethyl alcohol $(10 \mathrm{ml}$ - alcohol: $170.8 \mathrm{mg}$ - HAP). The deposition time was 30 minutes, after which the excess suspension from the por-Si surface was removed.

\subsection{The IR-spectroscopy method}

IR spectra were recorded by the Fourier spectrometer Perkin Elmer Spectrum100 with the prefix of disturbed total internal reflection (FTIR). Also, for comparison, IR spectra were taken by the FSM 2201 with the diffuse reflection prefix. 


\section{Analysis of results}

The Figs. bellow show the comparative IR spectra measured on the FSM-2201 spectrometer for glucose, the control sample of the plate, samples with $6 \%$ and $12 \%$ glucose solutions on the por-Si (Fig. 2). In the
Figs., the red color indicates the control samples with the rough ground (indicated by the letter $\mathrm{N}$ ) and polished (indicated by the letter $\mathrm{X}$ ) surface, blue samples with $6 \%$ glucose solution, green samples with $12 \%$ glucose solution, and pink spectrum of glucose powder.

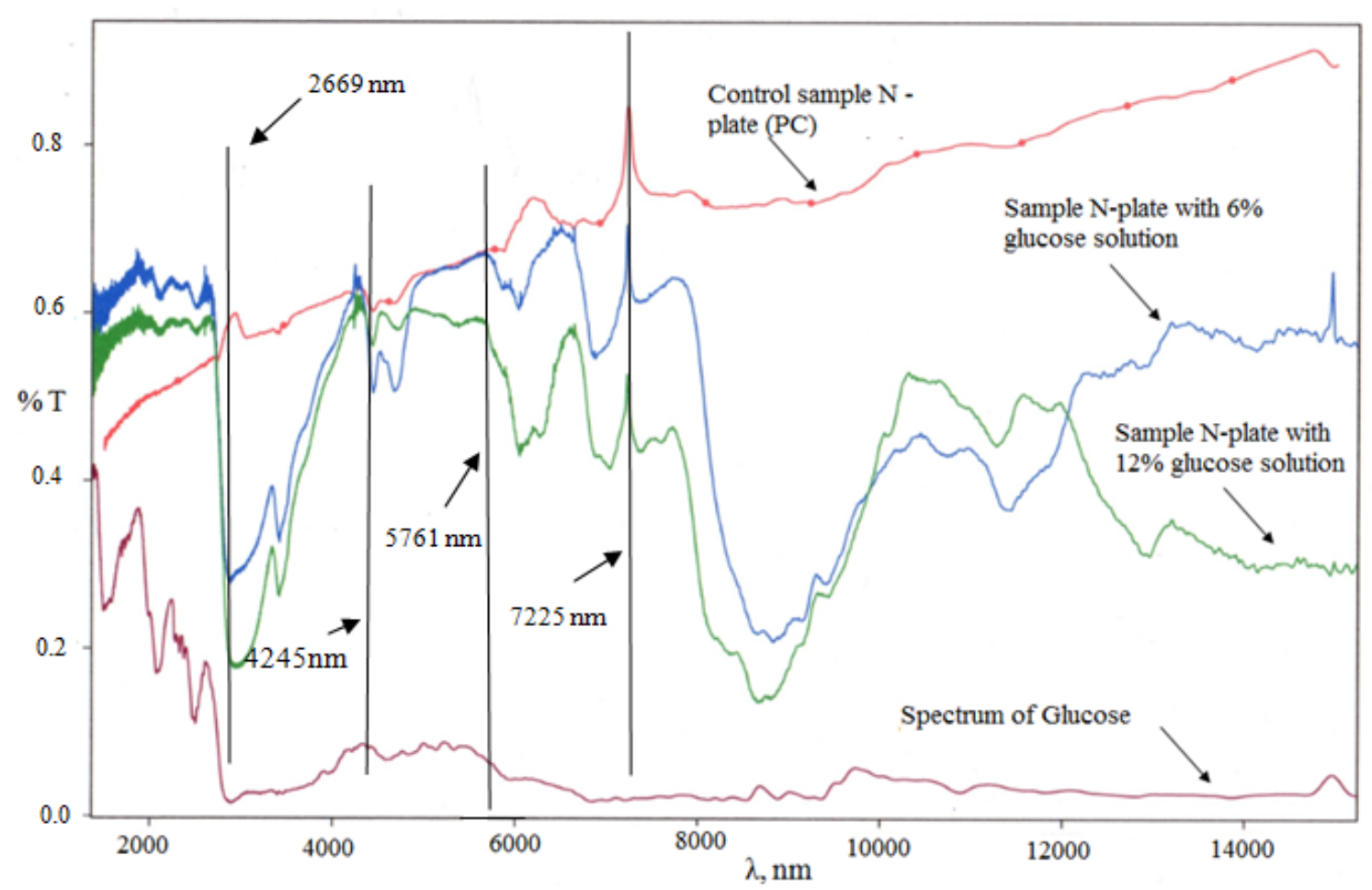

(a)

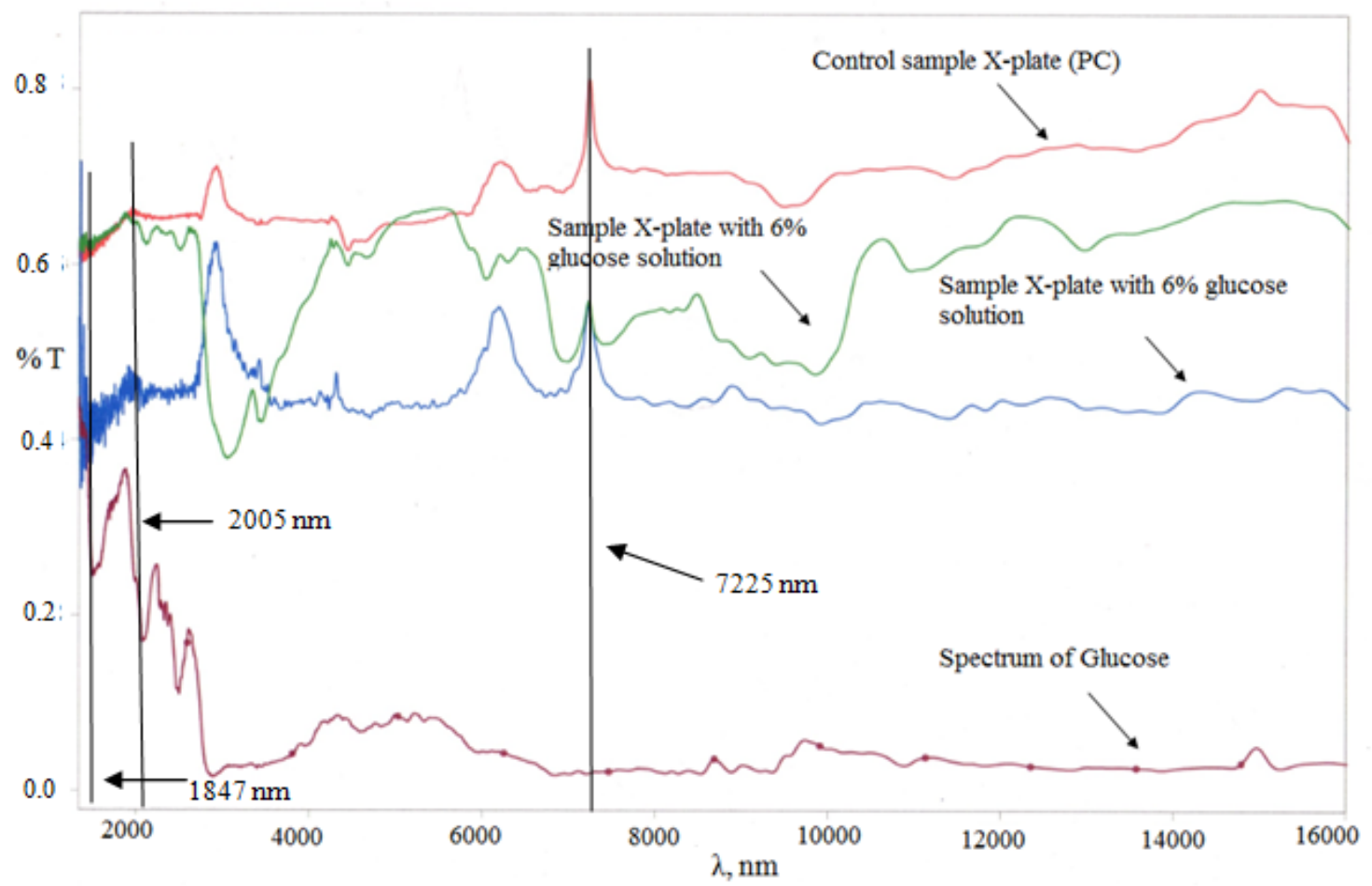

(b)

Fig. 2 (a) IR spectra for N-plate with rough ground surface; (b) IR spectra for X-plate with polished surface. 
The figures demonstrate that the saturation of the pores with an aqueous solution of glucose significantly changes the appearance of the IR spectrum (red lines in comparison with blue and green); this is especially noticeable for samples with a polished surface. Spectra of the nanocomposite samples of por-Si with glucose are impossible to obtain as a simple superposition of the spectra of the original por-Si and powder glucose. Certain absorption bands are responsible for silicon, and some bands for the presence of glucose in the pores of the samples. Absorption bands of porous silicon are clearly visible: peak $7225 \mathrm{~nm}, 4245 \mathrm{~nm}, 5761 \mathrm{~nm}$. The bands responsible for the presence of glucose can be observed at $1847 \mathrm{~nm}, 2005 \mathrm{~nm}, 2669 \mathrm{~nm}$. These bands can identify the presence of glucose in the liquid. However, for samples with different surface treatment, both the height and position of the glucose peaks are different. Therefore, for the quantitative analysis of the glucose content in the nanocomposite, some unification of the surface of the samples is necessary.

The analysis by IR spectroscopy was carried out for samples of nanocomposite por-Si + HAP on the spectrometer "Perkin Elmer Spectrum 100". The spectra of the initial silicon wafer, a plate with a porous layer, a porous layer saturated with HAP and a powder of por-Si nanocomposite with HAP were measured. Identification of absorption bands was carried out according to the tables of characteristic frequencies on the basis of literature and reference data [20,21].

The additional absorption bands appear in the IR spectrum of the por-Si (Fig. 3(2)) in comparison with silicon. The por-Si surface is covered by $\mathrm{SiH}_{2}$ groups. This is evidenced by the presence of the absorption band $624 \mathrm{~cm}^{-1}$ corresponding to the deformation vibrations. In order to determine whether hydroxyapatite is contained in the pores, the IR spectrum of hydroxyapatite itself is given (Fig. 3(3)). The identification method revealed that the absorption peaks in both samples correspond to each other, which indicates the HAP content in the pores of silicon. The presence of HAP in the porous layer significantly changes the appearance of the IR spectra of the samples (Fig. 3(4)). IR spectrum of por-Si + HAP powder is shown in figure $3 / 5$ (Fig. 3(5)). Absorption peaks at $1062 \mathrm{~cm}^{-1}, 977 \mathrm{~cm}^{-1}, 874 \mathrm{~cm}^{-1}, 604 \mathrm{~cm}^{-1}$, clearly expressed in the HAP spectrum, are present in the spectra of both nanocomposite and nanocomposite powder. At the same time, no additional peaks appear in the spectra. Hence, we can conclude that some new compounds in the saturation of the pores HAP is not formed, that is, the chemical interaction of por-Si and HAP is absent.

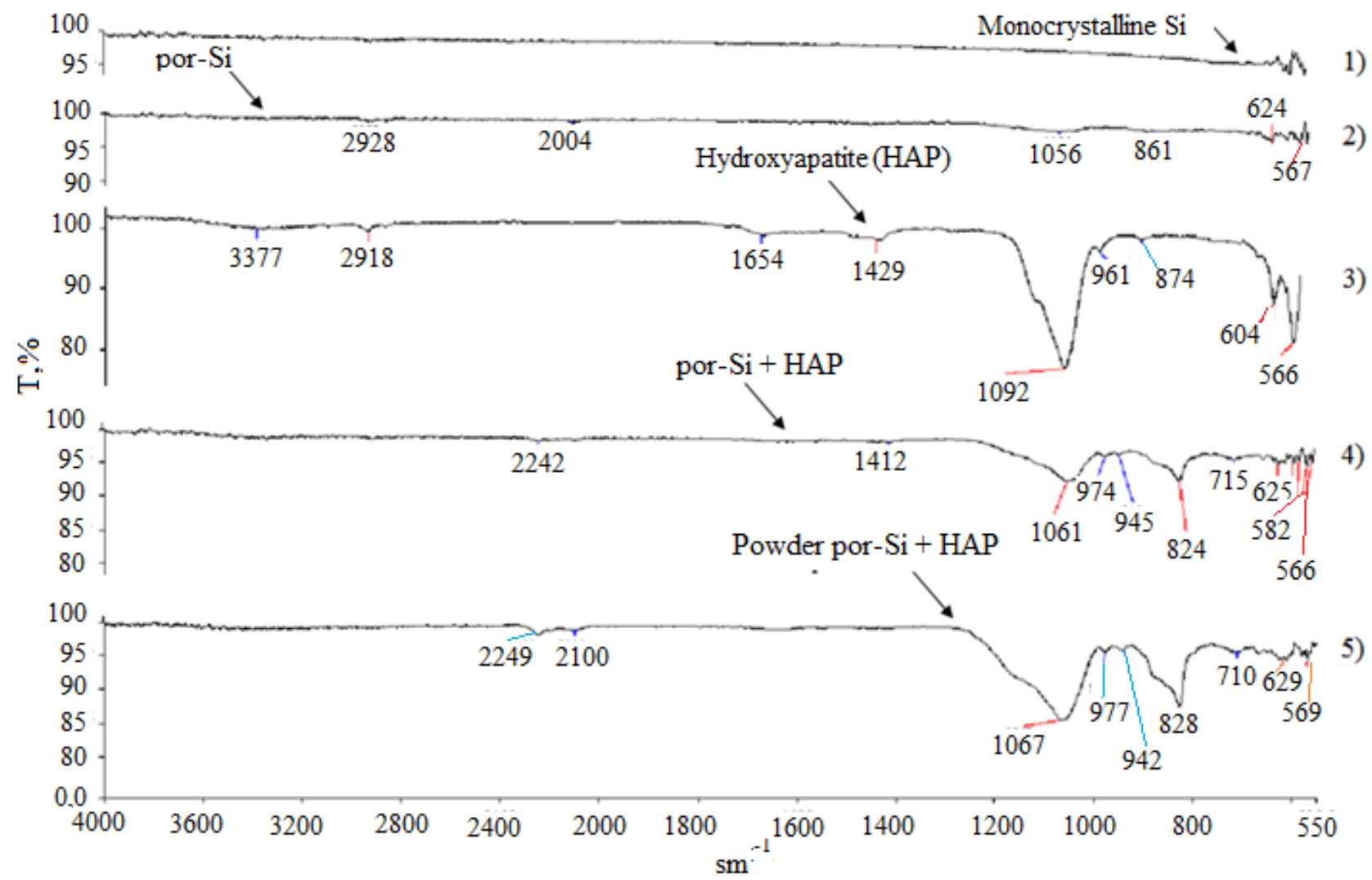

Fig. 3 IR spectra 1) monocrystalline $\mathrm{Si}$, 2) por-Si, 3) hydroxyapatite, 4) por-Si + HAP, 5) por-Si + HAP Powder obtained on the FSM spectrometer Perkin Elmer Spectrum100. 


\section{Conclusions}

The results of the analysis of the work may be concluded as bellow.

1. IR spectroscopy study of por-Si + glucose nanocomposites approve that the presence of glucose in the pores significantly changes the transmission spectra of the samples: the spectra show new bandwidth at $1847 \mathrm{~nm}, 2005 \mathrm{~nm}, 2669 \mathrm{~nm}$. For the development of a por-Si-based material suitable for use in a glucose biosensor, it is necessary to provide for the unification of the surface of the samples.

2. IR spectroscopy revealed that there is no chemical interaction between the substances of hydroxyapatite and porous silicon. On the IR spectra of all por-Si samples with HAP there are only peaks corresponding to the bonds in the por-Si or HAP.

It may be concluded that porous silicon is a promising material for the creation of glucose biosensor and the nanocomposite systems por-Si + HAP are suitable for the manufacture of biomaterial for bone implants and drugs for the treatment of osteoporosis.

\section{Disclosures}

All authors declare that there is no conflict of interests in this paper.

\section{References}

1. M. Simion, I. Kleps, T. Neghina, A. Angelescu, M. Miu, A. Bragaru, M. Danila, E. Condac, M. Costache, and L. Savu, "Nanoporous silicon matrix used as biomaterial," Journal of Alloys and Compounds 434-435, 830-832 (2007).

2. O. I. Ksenofontova, A. V. Vasin, V. V. Egorov, , A. V. Bobyl', F. Y. Soldatenkov, E. I. Terukov, V. P. Ulin, N. V. Ulin, and O. I. Kiselev, "Porous silicon and its applications in biology and medicine," Technical Physics59(1), 6677 (2014).

3. N. V. Latuhina, G. A. Pisarenko, A. V. Volkov, and V. A. Kitaeva, "Fotochuvstvitel'naya matrica na osnove poristogo mikrokristallicheskogo kremniya," Vestnik Samarskogo gos. universiteta. Estestvennonauchnaya seriya 5(86), 115-121 (2011) [in Russian].

4. C. Lee, H. Kim, C. Hong, M. Kim, S. S. Hong, D. H. Lee, and W. I. Lee, "Porous silicon as an agent for cancer thermotherapy based on near-infrared light irradiation," Journal of Materials Chemistry 18(40), 4790-4795 (2008).

5. L. A. Osminkina, K. P. Tamarov, A. P. Sviridov, R. A. Galkin, M. B. Gongalsky, V. V. Solovyev, A. A. Kudryavtsev, and V. Y. Timoshenko, "Photoluminescent biocompatible silicon nanoparticles for cancer theranostic applications," Journal of Biophotonics 5(7), 529-535 (2012).

6. L. Pramatarova, E. Pecheva, D. Dimova-Malinovska, R. Pramatarova, U. Bismayerc, T. Petrov, and N. Minkovski, "Porous silicon as a substrate for hydroxyapatite growth," Vacuum 76(2-3), 135-138 (2004).

7. J. L. Coffer, M. A. Whitehead, D. K. Nagesha, P. Mukherjee, G. Akkaraju, M. Totolici, R. S. Saffie, and L. T. Canham, "Porous silicon-based scaffolds for tissue engineering and other biomedical applications," Physica Status Solidi (A) 202(8), 1451-1455 (2005).

8. T. J. Barnes, L. J. Karyn, and C. A. Prestidge, "Recent advances in porous silicon technology for drug delivery," Therapeutic Delivery 4(7), 811-823 (2013).

9. Y. M. Spivak, N. R. Nigmadzyanova, "Poluchenie poristogo kremhiya dlya primeneniya v adresnoy dostavke lekarctv," Molodoy ucheniy 10, 208-212 (2014) [in Russian].

10. S. Dhanekar, S. Jain, "Porous silicon biosensor: Current status," Biosensors and Bioelectronics 41, 54-64 (2013).

11. B. Gupta, Y. Zhu, B. Guan, P. J. Reece, and J. Gooding, "Functionalised porous silicon as a biosensor: emphasis on monitoring cells in vivo and in vitro," The Analyst 138(13), 3593-3615 (2013).

12. D. Fan, G. R. Akkaraju, E. F. Couch, L. T. Canham, and J. L. Coffer, "The role of nanostructured mesoporous silicon in discriminating in vitro calcification for electrospun composite tissue engineering scaffolds, "Nanoscale 3(2), 354-61 (2011).

13. M. A. Whitehead, D. Fan, G. R. Akkaraju, L. T. Canham, and J. L. Coffer, “Accelerated calcification in electrically conductive polymer composites comprised of poly(epsilon-caprolactone), polyaniline, and bioactive mesoporous silicon," Journal of Biomedical Materials Research Part A 83A(1), 225-234 (2007).

14. E. M. Carlisle, "Silicon as a trace nutrient," Science of The Total Environment 73(1-2), 95-106 (1988).

15. E. V. Berlova, A. S. Domchenkova, V. A. Zhukova, and N. V. Latuhin, "Nanokomposity poristogo kremniya s gidroksiapapitom dlyamedicinskih prilozheniy," Sbornic materialov V Vserossiyskoy konferencii po nanomaterialam "Nano 2013", 382 (2013) [in Russian].

16. S. Zairi, C. Martelet, N. Jaffrezic-Renault, R. M'gaïeth, H. Maâref, and R. Lamartine, "Porous silicon a transducer material for a high-sensitive (bio)chemical sensor: effect of a porosity, pores morphologies and a large surface area on a sensitivity," Thin Solid Films 383(1-2), 325-327 (2001).

17. Y. A. Vashpanov, I. P. Konup, V. A. Smyntyna, and V. A. Ivanica, "Vliyanie adsorbcii biologicheskih molecul na elektronnye parametry poristogo kremniya," Vestnic Odeskogo nacional'nogo Universiteta 11(7), 39-46 (2006) [in Russian]. 
18. N. Y. Arbatskaya, "Sovremennye pribory dlya samokontrolya urovnya sahara krovi," Lechashchiy vrach 5, 46-53 (2005).

19. "Nanotehnologii v medicine. Realnost ili poka tolko mif?" Nano News Net [in Russian].

20. N. A. Bazaev, Y. P. Masloboev, and S. V. Seliszhev, "Opticheskie metody neinvazivnogo opredeleniya urovnya glukozy v krovi," Medicinskaya tehnika 6(270), 29-33 (2011).

21. A. L. Smeth, Applied IR spectroscopy. Fundamentals, techniques and analytical problem solving, Wiley, New York (1979).

22. L. A. Kazicyna, N. B. Kupletskaya, Primenenie UF-, IK- I YaMR-spectroscopii v organicheskoy himii, Vysshaya shkola, Moscow (1971) [in Russian]. 